\title{
An Echo: Professor Tascioglu
}

\author{
(1) Büşra Can
}

Marmara University Faculty of Medicine, Department of Internal Medicine, Division of Geriatrics, Istanbul, Turkey

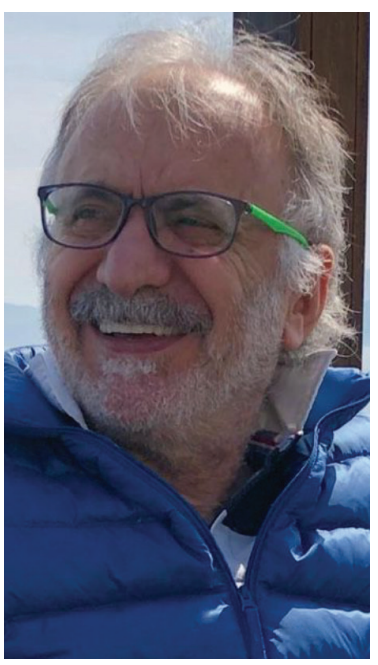

Professor Tascioglu greets the patient with a warm handshake. My coresident presents the history of the patient, leaving us with an extensive differential diagnosis. He silently listens till the end. Of all the possible next steps, he chooses to palpate the patient's spleen. We are all the more astonished when he comes up with a diagnosis on the spot. He turns to us to explain. "the size and the elasticity of the spleen is almost specific" (I am familiar with causes of splenomegaly, but spleen elasticity?). At the end of two weeks of laboratory tests, cytogenetic testing, scans, and biopsies, he proves right yet again.

Learning to become a doctor is certainly an arduous climb. In ancient Greece and Rome, the practice of medicine was considered a craft that required an apprenticeship. Although clinical guidelines on almost every subject are increasingly enmeshed in our practice, we still need experienced seniors to help master the many facets of this "craft." Personally, I have had the privilege of getting to know invaluable professors over the course of my career, who helped me become the physician that I am today. Professor Tascioglu was one of them.

I first met him when I was a third-year medical student. The joy of teaching was almost tangible in his overcrowded lectures. He brought intriguing cases to discuss, asked questions with just the right amount of challenge, and never put us under too much stress. Whenever we got a question right, his eyes would beam like a father proud of his children.
Once I consulted the professor about my mother for what I would now call a trivial problem. I knew he never turned down relatives of students or hospital staff who sought his medical advice. His kindness and humility that day taught me more than any textbook on medical ethics and deontology.

Honestly, he was the reason why most of us chose internal medicine for a residency, me included. He was the head of the general medicine ward, which was on the fourth floor, above hematology. There were more than thirty beds on the ward, which consisted of rooms aligned on an unreasonably long corridor. His room was located at the entrance, where he ran an outpatient clinic, outside of which a queue of patients was always present. Sometimes he would call our names one by one to come see a rare sign, his voice echoing throughout the corridor. During ward rounds, we listened attentively as he enthusiastically led the crowd of interns, residents, and fellows from bedside to bedside. It was not stress or fear that motivated us to work; it was the pleasure of learning (the head nurse scared us a bit, though).

His skills in diagnostics were exceeded only by his humanity and compassion. Anyone could tell that he loved his job, that he loved people. He would hold the hands of the octogenarian patient and chat with her for fifteen minutes about her grandkids like it was the most natural thing to do during a ward round. Where we saw the skin rash of vasculitis, he saw a fragile woman who needed cheering up. Sometimes he would criticize the latest novel he read before going on to explain why he thought sarcoidosis was the most likely diagnosis for the lady who looked exactly like his niece!

He had a genuine smile on his face no matter what. He exuded positivity to every patient, nurse, doctor, and orderly around him, and we could not help but smile back. He appreciated every member of his team and had their back.

Address for Correspondence: Büşra Can, Marmara University Faculty of Medicine, Department of Internal Medicine, Division of Geriatrics, Istanbul, Turkey

Phone: +90 21662545 45/9128 E-mail: alpabusra@hotmail.com ORCID: orcid.org/0000-0002-7170-8044

Received: 26.05.2021 Accepted: 30.06.2021

Cite this article as: Can B. An Echo: Professor Tascioglu. Eur J Geriatr Gerontol 2021;3(2):38-39

${ }^{\circledR}$ Copyright 2021 by the Academic Geriatrics Society / European Journal of Geriatrics and Gerontology published by Galenos Publishing House. 


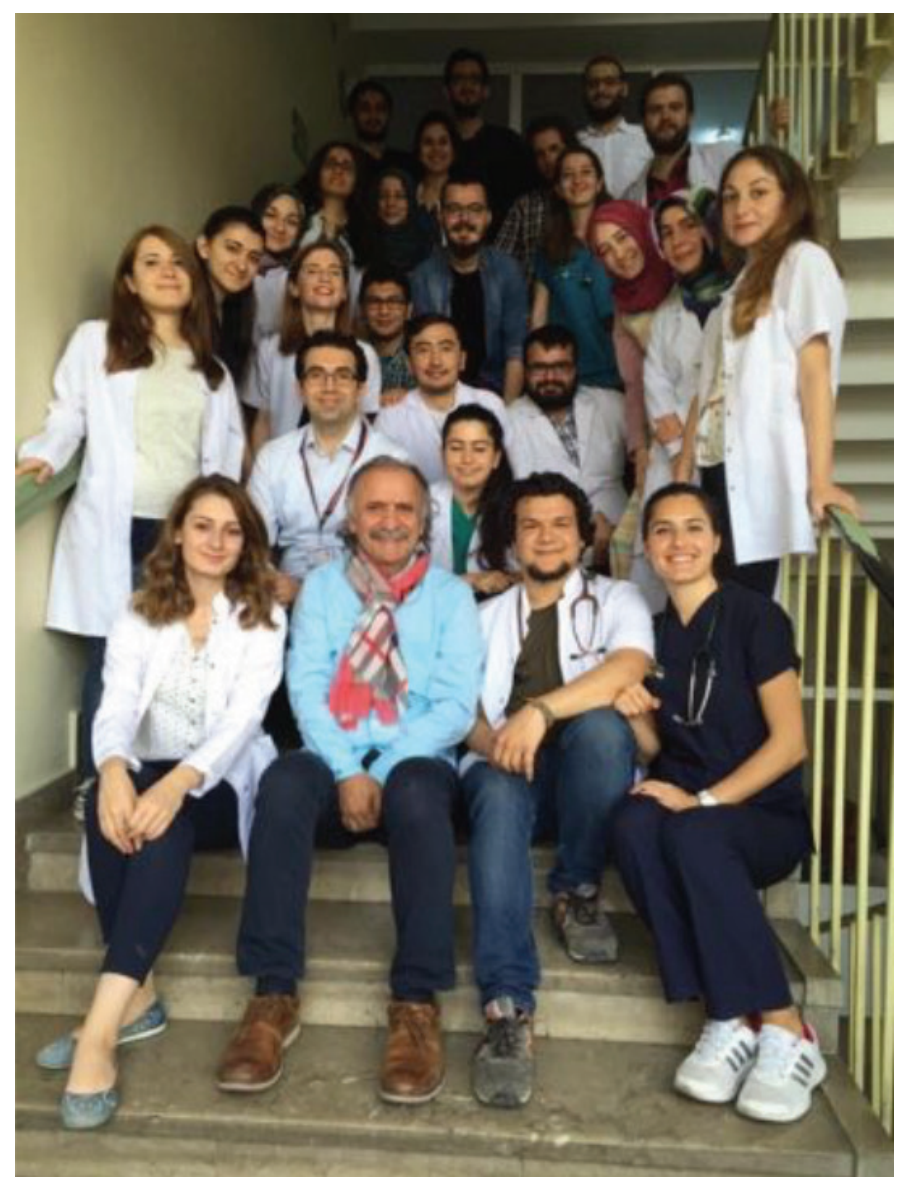

We learned from his colleagues that when the professor was a young resident, he used to stay late to do extra work and never got home earlier than 8:00 o'clock in the evening. After forty years in practice, he could have considered retirement, but he preferred to impart his knowledge and experience to the younger generation instead.
March 2020 marked the beginning in Turkey of the Coronavirus disease-2019 outbreak, which he never braced for. He is believed to have contracted the virus from one of the first patients in the country. He kept assuring everyone around him that he was going to be $\mathrm{OK}$, although deep down, his amazing clinical intuition must have told him otherwise. Right before he was admitted to the intensive care unit, while still conscious, he encouraged the intensive care team to test experimental drugs on him. It was an exemplary end to an exemplary life. Even people who hadn't ever met the professor in person shed tears of grief.

In the ancient city of İstanbul, where I live, historical monuments perpetuate memories of the past. Like an architect who makes timeless buildings, I believe a teacher achieves immortality through his students. It has been a year since we lost Professor Tascioglu, but "deceased" he is not.

He is there when I diagnose a subtle malignancy. He is there when I congratulate an intern. He is there when I hold the trembling hands of a frail octogenarian and ask after her grandkids. His familiar voice will continue to echo in the neuronal network of medical students from generation to generation. Timeless, like the ancient city.

Keywords: COVID-19, internal medicine, mentor, obituary, Prof. Tascioglu

\section{Ethics}

Peer-review: Internally peer-reviewed.

Financial Disclosure: The author declared that this study received no financial support. 